\title{
Hak Politik Tentara Nasional Indonesia dan Kepolisian Negara Republik Indonesia Pasca Reformasi
}

\author{
Ni'matul Huda \\ Fakultas Hukum Universitas Islam Indonesia \\ Jl. Tamansiswa No. 158 Yogyakarta \\ penerbitan.fh@uii.ac.id
}

\begin{abstract}
The government policy to temporarily 'postpone' the voting right of the army and police after the reform has become an interesting topic of discussion among the people. This study discussed: first, what are the implications of the political and state administration reform 1998 on the national army dual function? This study was a normative research using primary and secondary research materials. This study employed statute and historical approaches. This study concluded that first, the implications of the political and state admisnistration reform 1998 on the national army dual function were the institutional separation between army and police, the abolishment of army membership in People's Consultative Assembly, and the temporary postponement of voting right of national army and police until General Election of 2014. Second, national army and police were not allowed to use their rights to vote in the General Election after the reform due to the fact that the dual function of army during the New Order had weakened the democracy functions.
\end{abstract}

Key words: Political right, reform

\begin{abstract}
Abstrak
Kebijakan pemerintah yang 'menunda' sementara penggunaan hak pilih TNI dan Polri pasca reformasi menjadi perbincangan menarik di masyarakat. Penelitian ini mengkaji: pertama, apa implikasi reformasi politik dan ketatanegaraan 1998 terhadap dwifungsi ABRI? Kedua, mengapa TNI dan Polri tidak diperkenankan untuk menggunakan hak pilihnya dalam Pemilu pasca reformasi? Penelitian ini merupakan penelitian normatif. Bahan yang digunakan dalam penelitian ini bersumber dari bahan hukum primer dan sekunder, dengan pendekatan perundang-undangan dan pendekatan historis. Penelitian ini menyimpulkan, pertama, implikasi reformasi politik dan ketatanegaraan 1998 terhadap dwifungsi $A B R I$ adalah dipisahkannya TNI dan Polri secara kelembagaan, dihapuskannya keanggotaan ABRI di MPR, serta adanya penundaan sementara penggunaan hak pilih TNI dan Polri hingga Pemilu 2014. Kedua, TNI dan Polri tidak diperkenankan untuk menggunakan hak pilihnya dalam Pemilu pasca reformasi dilatarbelakangi oleh kebijakan dwifungsi ABRI di masa Orde Baru yang merusak sendi-sendi demokrasi.
\end{abstract}

Kata kunci: Hak politik, reformasi 


\section{Pendahuluan}

Selama pemerintahan Orde Baru, TNI dan Polri yang menyatu dalam ABRI, telah terjadi dominasi militer pada hampir di semua aspek kehidupan berbangsa dan bernegara. Militer juga difungsikan sebagai pilar penyangga kekuasaan. Konsep ini muncul sebagai dampak dari implementasi konsep dwifungsi ABRI yang telah menjelma menjadi multifungsi. Akibatnya peran ABRI dalam kehidupan bangsa telah melampaui batas-batas konvensional keberadaannya sebagai alat negara di bidang pertahanan dan keamanan. Integrasi status Polri yang berwatak sipil ke dalam tubuh ABRI dapat dikatakan sebagai pengingkaran terhadap prinsip demokrasi. ${ }^{1}$

Pengukuhan ABRI sebagai kekuatan sosial politik baru terjadi secara legal formal setelah keluarnya UU No. 20 Tahun 1982 tentang Ketentuan Pokok Pertahanan Keamanan Negara. Lahirnya UU ini untuk lebih memantapkan landasan hukum dwifungsi ABRI, yang sebelumnya hanya diatur dalam Ketetapan MPR. Dalam UU No. 20 Tahun 1982 ditegaskan bahwa pengaturan peran sosial politik ABRI adalah sebagai kekuatan sosial yang bertindak selaku dinamisator dan stabilisator. Hal ini sebenarnya merupakan sebuah contradiction in terminis, karena bagaimana mungkin dinamisator dan stabilisator sekaligus dipegang oleh orang yang sama.

Setidak-tidaknya ada dua pasal yang mendukungnya. Pasal 26 menyebutkan, Angkatan Bersenjata mempunyai fungsi sebagai kekuatan pertahanan keamanan dan sebagai fungsi kekuatan sosial. Pasal 28 ayat (1) menegaskan, Angkatan Bersenjata sebagai kekuatan sosial bertindak selaku dinamisator dan stabilisator yang bersama-sama kekuatan sosial lainnya memikul tugas dan tanggungjawab mengamankan dan mensukseskan perjuangan bangsa dalam mengisi kemerdekaan. Sementara itu dalam ayat (2) menyatakan, bahwa dalam melaksanakan fungsi sosial, Angkatan Bersenjata diarahkan agar secara aktif mampu meningkatkan dan memperkokoh ketahanan nasional dengan ikut serta dalam pengambilan keputusan mengenai masalah kenegaraan dan pemerintahan, serta mengembangkan Demokrasi Pancasila dan kehidupan konstitusionil berdasarkan UUD $1945 .^{2}$

Berdasarkan legalitas ini maka ABRI tampil sebagai kekuatan yang mendominasi pemerintahan Orde Baru. Day-to-day politics menyebabkan keterlibatan

\footnotetext{
${ }^{1}$ Muh. Fajrul Falaakh, dkk (Tim Penulis), Implikasi Reposisi TNI-Polri di Bidang Hukum, FH UGM, Yogyakarta, 2001, hlm. 250.

${ }^{2}$ Ibid., hlm. 254-255.
} 
ABRI di bidang sosial politik lebih menonjol ketimbang perannya sebagai alat negara di bidang pertahanan dan keamanan negara. Atas nama stabilitas dan pengamanan terhadap Pancasila dan UUD 1945, ABRI telah mendominasi hampir semua relung kehidupan bernegara yang bersifat non-militer, dari tingkat pusat sampai tingkat daerah. $^{3}$

Di lapangan politik, lembaga legislatif yang identik dengan pemilihan umum, pada masa Orde Baru, Pemilu pertama digelar pada 1971. TNI dan Polri (ABRI) tidak menggunakan hak pilihnya, tetapi ABRI diberi kompensasi jatah satu fraksi di DPR/MPR (100 orang) dan DPRD. Pengkaplingan jabatan-jabatan sipil oleh ABRI ini sangat mempersempit ruang gerak sipil untuk berperan pada jabatan-jabatan yang merupakan domainnya. Dengan demikian, keputusan-keputusan penting dalam penyelenggaraan kehidupan berbangsa dan bernegara banyak yang lahir dari tangan militer. ${ }^{4}$

Keterlibatan ABRI dalam dunia politik di era Orde Baru merupakan implementasi dari pelaksanaan dwifungsi ABRI. Artinya, selain fungsi pertahanan dan keamanan, TNI juga memainkan fungsi sosial politik. Di samping itu, ABRI juga bermain di jabatan pemerintahan pusat hingga di daerah, bahkan menjadi anggota kabinet.

Reformasi politik pada Mei 1998 telah membawa berbagai perubahan mendasar dalam kehidupan bernegara dan berbangsa Indonesia. Pertama, sejak jatuhnya Soeharto kita tidak lagi memiliki seorang pemimpin sentral dan menentukan. Munculnya pusat-pusat kekuasaan baru di luar negara, telah menggeser kedudukan seorang Presiden RI dari penguasa yang hegemonik dan monopolistik menjadi kepala pemerintahan biasa, yang sewaktu-waktu dapat digugat dan bahkan diturunkan dari kekuasaannya. Kedua, munculnya kehidupan politik yang lebih liberal, telah melahirkan proses politik yang juga liberal. Ketiga, reformasi politik juga telah mempercepat pencerahan politik rakyat. Semangat keterbukaan yang dibawanya telah memperlihatkan kepada publik betapa tingginya tingkat distorsi dari proses penyelenggaraan negara. Keempat, pada tataran lembaga tinggi negara, kesadaran untuk memperkuat proses checks and balances antara cabang-cabang kekuasaan telah berkembang sedemikian rupa, sampai melampaui konvensi yang selama ini dipegang - yakni "asas kekeluargaan" di dalam penyelenggaraan negara.

\footnotetext{
${ }^{3}$ Ibid.

${ }^{4}$ Ibid., hlm. 256.
} 
Kelima, reformasi politik telah mempertebal keinginan sebagian elite berpengaruh dan publik politik Indonesia untuk secara sistematik dan damai melakukan perubahan mendasar dalam konstitusi RI. ${ }^{5}$

Respon militer terhadap kuatnya tekanan masyarakat atas reformasi militer adalah diajukannya sejumlah perubahan organisasi TNI. Di antara perubahan tersebut meliputi: pemisahan Polri dari ABRI; perubahan staf sosial politik menjadi staf teritorial; penghapusan kekaryaan ABRI melalui pensiun atau alih status; pengurangan Fraksi ABRI di DPR, DPRDI/II. Selain kebijakan pengurangan jumlah anggota Fraksi ABRI di DPR/DPRD yang melibatkan proses negosiasi yang cukup ketat di DPR, kebijakan-kebijakan lainnya terkait perubahan organisasi tampaknya dirumuskan dan ditentukan oleh ABRI sendiri. ABRI memperkenalkan paket perubahan dimaksud sebagai implementasi dari apa yang mereka sebut sebagai "Paradigma Baru" ABRI. ${ }^{6}$

Sebagai akibat dari berbagai tuntutan tersebut akhirnya pemerintah mengambil sikap politik bahwa TNI dan Polri tidak boleh melakukan politik praktis yang dituangkan dalam berbagai peraturan perundang-undangan. Muncul berbagai permasalahan, apakah larangan tersebut tidak bertentangan dengan demokrasi dan HAM? Mengapa pemerintah sampai mengambil tindakan tegas untuk menangguhkan hak pilih TNI dan Polri? Sampai kapan penangguhan tersebut?

\section{Rumusan Masalah}

Berdasarkan latar belakang masalah yang diuraikan di atas, maka dirumuskan permasalahan yang hendak diteliti sebagai berikut. Pertama, apa implikasi reformasi politik dan ketatanegaraan 1998 terhadap dwifungsi ABRI? Kedua, mengapa TNI dan Polri tidak diperkenankan untuk menggunakan hak pilihnya dalam Pemilu pasca reformasi?

${ }^{5}$ Indria Samego, Perubahan Politik dan Amandemen UUD 1945, Makalah dalam Seminar dan Lokakarya Nasional "Evaluasi Kritis Atas Proses dan Hasil Amandemen UUD 1945” yang diselenggarakan Keluarga Alumni Universitas Gadjah Mada Yogyakarta, 8-10 Juli 2002.

${ }^{6}$ Donni Edwin, "Reformasi Militer Kepemimpinan Sipil vs Tentara" dalam AE Priyono dkk (Tim Penulis), Warisan Orde Baru, Institut Studi Arus Informasi bekerjasama Universitas Melbourne dan AusAid, Jakarta, 2005, hlm. 75. 


\section{Tujuan Penelitian}

Adapun tujuan dari penelitian ini adalah untuk mengetahui dan menganalisis: Pertama, implikasi reformasi politik dan ketatanegaraan 1998 terhadap dwifungsi ABRI. Kedua, latar belakang TNI dan Polri tidak diperkenankan untuk menggunakan hak pilihnya dalam Pemilu pasca reformasi.

\section{Metode Penelitian}

Objek di dalam penelitian ini adalah reformasi politik dan ketatanegaraan serta implikasinya terhadap hak politik TNI dan Polri pasca reformasi. Bahan hukum primer berupa peraturan perundang-undangan yang terkait dengan permasalahan yang diteliti, terutama UUD 1945, Ketetapan MPR No. VI/MPR/2000 tentang Pemisahan TNI dan Polri, Ketetapan MPR No. VII/MPR/2000 tentang Peran TNI dan Peran Polri, Undang-Undang No. 3 Tahun 1999 tentang Pemilu, UU No. 4 Tahun 1999 tentang Susunan dan Kedudukan MPR, DPR dan DPRD, UU No. 12 Tahun 2003 tentang Pemilihan Umum Anggota DPR, DPD, dan DPRD, UU No. 23 Tahun 2003 tentang Pemilihan Umum Presiden dan Wakil Presiden, UU No. 34 Tahun 2004 tentang Tentara Nasional Indonesia, UU No. 10 Tahun 2008 tentang Pemilihan Umum DPR, DPD dan DPRD, UU No. 8 Tahun 2012 tentang Pemilihan Umum DPR, DPD dan DPRD.

Bahan hukum sekunder berupa buku-buku literatur, disertasi, jurnal yang relevan, risalah-risalah sidang DPR, tulisan-tulisan ilmiah, hasil-hasil seminar, penelitian terdahulu, artikel, dan lain-lain. Penelitian ini menggunakan pendekatan perundang-undangan (statute approach), yaitu mendekati permasalahan yang diteliti dari sudut pandang hukum positif, dan pendekatan historis (historical approach) untuk melihat perjalanan historis kebijakan mengenai hak pilih dan dipilih TNI dan Polri dalam sejarah Indonesia pasca reformasi. Teknik pengumpulan bahan hukum yang digunakan dalam penelitian ini adalah studi kepustakaan, yaitu mengkaji berbagai peraturan perundang-undangan atau literatur-literatur yang berhubungan dengan permasalahan yang diteliti berupa: UUD 1945, Ketetapan MPR No. VI/MPR/2000 tentang Pemisahan TNI dan Polri, Ketetapan MPR No. VII/MPR/2000 tentang Peran TNI dan Peran Polri, Undang-Undang No. UU No. 3 Tahun 1999 tentang Pemilu, UU No. 12 Tahun 2003 tentang Pemilihan Umum Anggota DPR, DPD, dan DPRD, UU No. 23 Tahun 2003 tentang Pemilihan Umum Presiden dan Wakil Presiden, UU 
No. 34 Tahun 2004 tentang Tentara Nasional Indonesia, UU No. 10 Tahun 2008 tentang Pemilihan Umum Anggota DPR, DPD dan DPRD, UU No. 8 Tahun 2012 tentang Pemilihan Umum DPR, DPD dan DPRD. Dalam penelitian ini, bahan-bahan yang terkumpul akan disistematisasi dan dianalisis secara kualitatif. Sistematisasi berarti membuat klasifikasi terhadap bahan-bahan hukum tersebut untuk memudahkan pekerjaan analisis dan konstruksi.

\section{Hasil Penelitian dan Pembahasan}

\section{Teori Demokrasi}

Sejarah tentang paham demokrasi itu menarik; sedangkan sejarah tentang demokrasi itu sendiri menurut Held membingungkan. ${ }^{7}$ Ada dua fakta historis yang penting. "Pertama, hampir semua orang pada masa ini mengaku sebagai demokrat. Beragam jenis rezim politik di seluruh dunia mendeskripsikan dirinya sebagai demokrasi. Namun demikian, apa yang dikatakan dan diperbuat oleh rezim yang satu dengan yang lain sering berbeda secara substansial. Demokrasi kelihatannya melegitimasi kehidupan politik modern: penyusunan dan penegakan hukum dipandang adil dan benar jika 'demokratis'. Pada kenyataannya tidak selalu demikian. Dari zaman Yunani kuno hingga sekarang mayoritas teoretikus di bidang politik banyak melontarkan kritik terhadap teori dan praktik demokrasi. Komitmen umum terhadap demokrasi merupakan fenomena yang terjadi baru-baru ini saja. Kedua, sementara banyak negara pada saat ini menganut paham demokrasi, sejarah lembaga politiknya mengungkap adanya kerapuhan dan kerawanan tatanan demokrasi. Sejarah Eropa pada abad ke-20 sendiri menggambarkan dengan jelas bahwa demokrasi merupakan bentuk pemerintahan yang sangat sulit untuk diwujudkan dan dijaga: Fasisme, Nazisme, dan Stalinisme hampir saja menghancurkannya. Demokrasi telah berkembang melalui perlawanan sosial yang intensif. Demokrasi juga sering dikorbankan dalam perlawanan serupa."

Demokrasi merupakan asas dan sistem yang paling baik di dalam sistem politik dan ketatanegaraan kiranya tidak dapat dibantah. Khasanah pemikiran dan preformansi politik di berbagai negara sampai pada satu titik temu tentang ini:

${ }^{7}$ David Held, Models of Democracy, diterjemahkan oleh Abdul Haris, Akbar Tandjung Institute, Jakarta, 2007, hlm. xxiii. 
demokrasi adalah pilihan terbaik dari berbagai pilihan lainnya. Sebuah laporan studi yang disponsori oleh salah satu organ PBB yakni UNESCO pada awal 1950-an menyebutkan bahwa tidak ada satu pun tanggapan yang menolak "demokrasi" sebagai landasan dan sistem yang paling tepat dan ideal bagi semua organisasi politik dan organisasi modern. Studi yang melibatkan lebih dari 100 orang sarjana barat dan timur itu dapat dipandang sebagai jawaban yang sangat penting bagi studi-studi tentang demokrasi. ${ }^{8}$

Hampir semua teoritisi - bahkan sejak zaman klasik - selalu menekankan bahwa sesungguhnya yang berkuasa dalam demokrasi itu adalah rakyat atau demos, populus. Oleh karena itu, selalu ditekankan peranan demos yang senyatanya dalam proses politik yang berjalan. Paling tidak, dalam dua tahap utama: pertama, agenda setting, yaitu tahap untuk memilih masalah apa yang hendak dibahas dan diputuskan; kedua, deciding the outcome, yaitu tahap pengambilan keputusan. ${ }^{9}$

Berangkat dari pemaknaan yang sama dan karenanya universal, demokrasi substansial, telah memberikan daya pikat normatif. Bahwa dalam demokrasi, mestinya berkembang nilai kesetaraan (egalitarian), keragaman (pluralisme), penghormatan atas perbedaan (toleransi), kemanusiaan atau penghargaan atas hakhak asasi manusia, "kebebasan”, tanggungjawab, kebersamaan, dan sebagainya. Secara substantif demokrasi melampaui maknanya secara politis. ${ }^{10}$

Di sisi lain, sebagai suatu sistem politik, demokrasi juga mengalami perkembangan dalam implementasinya. Banyak model demokrasi hadir di sini, dan itu semua tidak lepas dari ragam perspektif pemaknaan demokrasi substansial. Yang menjadikan demokrasi berkembang ke dalam banyak model, antara lain karena terkait dengan kreativitas para aktor politik di berbagai tempat dalam mendesain praktik demokrasi prosedural sesuai dengan kultur, sejarah dan kepentingan mereka.

Dalam sejarah teori demokrasi terletak suatu konflik yang sangat tajam mengenai apakah demokrasi harus berarti suatu jenis kekuasaan rakyat (suatu bentuk politik di mana warganegara terlibat dalam pemerintahan sendiri dan pengaturan sendiri) atau suatu bantuan bagi pembuatan keputusan (suatu cara

${ }^{8}$ Afan Gaffar, "Kualitas Pemilu Menentukan Kualitas DPR, Sebuah Sketsa", "Pengantar" dalam Dahlan Thaib dan Ni'matul Huda (ed.), Pemilu dan Lembaga Perwakilan Dalam Ketatanegaraan Indonesia, Jurusan HTN Fakultas Hukum UII, Yogyakarta, 1992, hlm. vi.

${ }_{9}^{9}$ Afan Gaffar, Politik Indonesia; Transisi Menuju Demokrasi, Pustaka Pelajar, Yogyakarta, 1999, hlm. 6.

${ }^{10}$ Akbar Tandjung, "Kata Pengantar", dalam David Held, Op.Cit., Hlm. x. 
pemberian kekuasaan kepada pemerintah melalui pemberian suara secara periodik). Konflik inti telah memunculkan tiga jenis atau model pokok demokrasi. ${ }^{11}$ Pertama, demokrasi partisipatif atau demokrasi langsung, suatu sistem di mana pengambilan keputusan tentang permasalahan umum melibatkan warga negara secara langsung. Ini adalah tipe demokrasi "asli" yang terdapat di Athena kuno, di antara tempattempat yang lain (seperti yang diuraikan di atas). Kedua, demokrasi liberal atau demokrasi perwakilan, suatu sistem pemerintahan yang menggunakan 'pejabat' yang dipilih untuk 'mewakili' kepentingan atau pendapat warga negara dalam daerah-daerah yang terbatas sambil tetap menjunjung tinggi ‘aturan hukum'. Ketiga, demokrasi yang didasarkan atas model satu partai (meskipun sementara orang mungkin meragukan apakah hal ini merupakan suatu model demokrasi juga).

Setiap tahap pergantian rezim selalu mengandung harapan-harapan baru berupa kehidupan yang lebih demokratis dibandingkan dengan pemerintahan sebelumnya. Jatuhnya Orde Lama yang digantikan Orde Baru, yang ditandai dengan ikutsertanya para teknokrat dari dunia akademis di pemerintahan, pada mulanya membawa angin segar dan harapan baru dalam kehidupan politik di Indonesia. Namun akibat inkonsistensi dalam sikap dan pemikiran dalam menegakkan nilai-nilai dasar demokrasi, pada akhirnya Orde Baru terseret dalam praktek-praktek pemerintahan pragmatis dan otoriter. Akibatnya hukum ditundukkan untuk mengabdi kepada sistem kekuasaan represif.

Michael van Langenberg menilai Orde Baru sejak 1965/1966 telah membangun sistem negara yang hegemonik, dengan formulasi ideologi sebagai tiang utamanya. Dengan demikian dasar dari konstruksi hegemoni negara adalah ketertiban, stabilitas, dan keamanan nasional. ${ }^{12}$

\section{HAM Bidang Politik}

Selama Orde Baru, HAM sipil dan politik banyak dilanggar dengan alasan untuk menjaga stabilitas politik demi kelancaran pembangunan ekonomi, korupsi, kolusi dan nepotisme merajalela, penyalahgunaan kekuasaan meluas, hukum merupakan subordinasi dari kekuasaan politik, dan campur tangan eksekutif terhadap kekuasaan kehakiman sudah menjadi cerita biasa. Beberapa keputusan

\footnotetext{
${ }^{11}$ David Held, Demokrasi \& Tatanan Global Dari Negara Modern Hingga Pemerintahan Kosmopolitan, Pustaka Pelajar, Yogyakarta, 2004, hlm. 5-6.

${ }^{12}$ Michael van Langenberg, Negara Orde Baru: Bahasa, Ideologi, Hegemoni, dalam Yudi Latif dan Idi Subandy (ed.), Bahasa dan Kekuasaan Politik. Wacana di Panggung Orde Baru, Cet. Kedua, Mizan, Bandung, 1996, hlm. 225.
} 
Mahkamah Agung jelas-jelas memperlihatkan pemihakannya terhadap kekuasaan, meski dengan akibat merugikan rakyat kecil, kebenaran dan keadilan sering dikesampingkan dengan alasan demi persatuan dan kesatuan bangsa, demi Pancasila, demi kepentingan umum, demi asas kekeluargaan dan sebagainya, meski itu merugikan HAM. ${ }^{13}$

Terdapat pula sikap ambivalen akibat pengaruh universal dan global yang mengharuskan penguasa untuk mengadopsi kecenderungan internasional yang diakui oleh bangsa-bangsa beradab, seperti tercermin pada kasus - untuk menyebut beberapa - diundangkannya UU No. 8 Tahun 1981 tentang Hukum Acara Pidana, UU No. 5 Tahun 1986 tentang PTUN dan terbentuknya Komnas HAM dengan Keppres No. 50 Tahun 1993 jo UU No. 39 Tahun 1999 tentang HAM yang membawa pesan-pesan demokratis.

Maraknya aktivitas pelbagai LSM yang bergerak di bidang studi dan advokasi hukum serta HAM, turut pula memberikan kontribusinya sendiri. Cukup lama kita merasakan bahwa wajah hukum kita berwajah ganda. Tidak dapat disangkal bahwa di samping krisis ekonomi yang dahsyat, sebenarnya langkah-langkah ambivalen tersebut merupakan rahmat tersembunyi (blessing in disguise) dan turut andil dalam kejatuhan Orde Baru. ${ }^{14}$

Derap reformasi yang mengawali lengsernya Orde Baru pada awal tahun 1998 pada dasarnya merupakan gerak kesinambungan yang merefleksikan komitmen bangsa Indonesia yang secara rasional dan sistematis bertekad untuk mengaktualisasikan nilai-nilai dasar demokrasi. Nilai-nilai dasar tersebut antara lain berupa sikap transparan dan aspiratif dalam segala pengambilan keputusan politik, pers yang bebas, sistem pemilu yang jujur dan adil, pemisahan TNI dan Polri, sistem otonomi daerah yang adil, dan prinsip good governance yang mengedepankan profesionalisme birokrasi lembaga eksekutif, keberadaan badan legislatif yang kuat dan berwibawa, kekuasaan kehakiman yang independen dan impartial, partisipasi masyarakat yang terorganisasi dengan baik serta penghormatan terhadap supremasi hukum.

Secara sadar pemerintah mengakui adanya "penyelewengan" hukum yang dilakukan oleh rezim masa lalu, sebagaimana yang tertuang dalam Ketetapan MPR

${ }^{13}$ Muladi, Demokratisasi, Hak Asasi Manusia, dan Reformasi Hukum di Indonesia, Cetakan Pertama, The Habibie Center, Jakarta, 2002, hlm. 8-9.

${ }^{14} \mathrm{Ibid}$. 
No. X/MPR/1998 tentang Pokok-pokok Reformasi Pembangunan Dalam Rangka Penyelamatan dan Normalisasi Kehidupan Nasional Sebagai Haluan Negara, Bab II butir c, yang berbunyi sebagai berikut: "Selama tiga puluh dua tahun pemerintahan Orde Baru, pembangunan hukum khususnya yang menyangkut peraturan perundangundangan organik tentang pembatasan kekuasaan Presiden belum memadai. Kondisi ini memberi peluang terjadinya praktek-praktek korupsi, kolusi, dan nepotisme serta memuncak pada penyimpangan berupa penafsiran yang hanya sesuai dengan selera penguasa. Telah terjadi penyalahgunaan wewenang, pelecehan hukum, pengabaian rasa keadilan, kurangnya perlindungan dan kepastian hukum bagi masyarakat."

Secara tegas koreksi terhadap penyelewengan Orde Baru juga dituangkan dalam Penjelasan Umum Bab III UU No. 25 Tahun 2000 tentang Program Pembangunan Nasional (Propenas) 2000-2004, yaitu: ${ }^{15}$ “Penegakan supremasi hukum berdasarkan nilai-nilai kebenaran dan keadilan serta penghormatan terhadap hak-hak asasi manusia secara universal mengalami degradasi. Kondisi tersebut, antara lain disebabkan oleh pemerintahan pada masa lalu tidak mencerminkan aspirasi masyarakat dan kebutuhan pembangunan yang bersendikan hukum agama dan hukum adat... dalam pembangunan hukum."

Untuk itu, Pemerintah Orde Reformasi ingin melakukan penataan ulang arah kebijakan hukum nasional sebagaimana tertuang dalam GBHN 1999. Arah Kebijakan Hukum dalam GBHN 1999 disebutkan antara lain: “Menata sistem hukum nasional yang menyeluruh dan terpadu dengan mengakui dan menghormati hukum agama dan hukum adat serta memperbaharui perundang-undangan warisan kolonial dan hukum nasional yang diskriminatif, termasuk ketidakadilan gender dan ketidaksesuaiannya dengan tuntutan reformasi melalui program legislasi."

Perintah dari MPR melalui GBHN 1999 tersebut kemudian ditindaklanjuti dengan dikeluarkannya UU No. 25 Tahun 2000 tentang Program Pembangunan Nasional (Propenas) Tahun 2000-2004, dengan melakukan penyusunan dan pembentukan peraturan perundang-undangan yang aspiratif dengan mengakui dan menghormati hukum agama dan adat melalui peningkatan peran Program Legislasi Nasional (Prolegnas).

Di tengah perubahan besar saat ini, ketika sejumlah anggota masyarakat Indonesia muncul dengan peran baru, kekuasaan tidak lagi menjadi milik segelintir

${ }^{15}$ Lihat Undang-Undang RI Nomor 25 Tahun 1999 tentang Program Pembangunan Nasional (Prolegnas), tahun 1999-2004, LN 206, Bab III Pembangunan Hukum. 
elite politik. Kekuasaan terbesar di banyak tempat dan kepada banyak orang. Mereka yang dulu lebih banyak pasif kini bangun mengambil prakarsa politik dan bertindak seolah mendapat mandat paling besar untuk menegakkannya.

Proses dialogis tentang format dan sistem berbangsa dan bernegara menuju demokrasi pun kini menjadi menu sehari-hari. Sayangnya, pada situasi seperti ini justru proses penegakan hukum masih saja mengalami banyak kendala. Bukan saja lantaran warisan sistem hukum yang buruk di masa lalu, situasi belakangan ini juga mendatangkan proses identifikasi politik baru bagi warga negara dengan segala klaimnya tentang hak dan kewajiban.

Dalam rezim hukum internasional HAM, hak politik, terutama hak untuk memilih dan dipilih, termasuk berpartisipasi dalam pemerintahan, merupakan hak dasar bagi setiap warga negara tanpa terkecuali. Hal ini juga telah ditegaskan dalam Pasal 27 ayat (1) UUD 1945. Pengurangan dan pembatasan terhadap hak untuk memilih dan dipilih, dengan berpedoman pada ketentuan Pasal 25 Kovenan Internasional Hakhak Sipil dan Politik, sebagaimana telah disahkan Indonesia melalui UU No. 12 Tahun 2005, dapat dibenarkan jika dilakukan dengan objektif dan masuk akal.

Apakah hak memilih dan dipilih untuk menjadi pejabat publik tertentu, termasuk anggota militer dan kepolisian dapat dikecualikan atau ditangguhkan? Sebagian ahli berpandangan hak memilih dan dipilih harus diberikan kepada setiap warga negara, tanpa terkecuali. Sementara sebagian ahli lainnya berpendapat, pengecualian atau penangguhan dapat dilakukan terhadap anggota militer, polisi, atau pejabat publik lainnya, sepanjang dengan alasan yang objektif dan masuk akal.

Pengecualian atau penangguhan hak memilih dan dipilih bagi anggota militer dan polisi, berangkat dari argumentasi bahwa tindakan tersebut merupakan ukuran yang diperlukan dan dibenarkan untuk memastikan netralitas administrasi Pemilu. Pandangan sebaliknya dikemukakan oleh para pendukung hak penuh bagi anggota militer dan polisi untuk berpartisipasi dalam Pemilu. Kelompok ini berpendapat, bahwa mendaftar dan memberikan suara bukanlah suatu tindakan politik. Pembatasan hanya boleh dilakukan untuk tidak menjadi anggota partai politik atau aktivis partai politik. ${ }^{16}$

Negara-negara di dunia juga beragam di dalam menerapkan ketentuan ini. Sebagian negara memberikan hak memilih dan dipilih secara penuh kepada anggota

${ }^{16}$ Nur Rosihin Ana, "Hak Pilih Anggota TNI/Polri dalam Pemilu Presiden 2014”, Majalah Konstitusi, No. 86April 2014, hlm. 42. 
militer atau polisi. Sebagian lagi hanya memberikan hak untuk memilih. Kemudian sebagian lainnya menangguhkan sama sekali. Negara-negara yang memberikan hak pilih kepada militer atau polisi yaitu Armenia, Australia, Belize, Bolivia, Bulgaria, Canada, China, Republik Czech, Perancis, Jerman, Israel, New Zealand, Nicaragua, Philippines, Poland, Russia, South Africa, Sweden, United Kingdom, United State, Venezuela, Ukraine, dan Vietnam. Sedangkan Negara-negara tanpa hak pilih bagi militer yaitu, Angola, Argentina, Brazil (di bawah pangkat sersan), Chad, Colombia, Republik Dominika, Ecuador, Guatemala, Honduras, Indonesia, Kuwait, Paraguay, Peru, Senegal, Tunisia, Turkey, Uruguay (di bawah pangkat kopral). ${ }^{17}$

Menurut jurisprudensi Putusan MK, pembatasan terhadap hak pilih seseorang, termasuk hak pilih TNI dan Polri juga sangat mungkin untuk dilakukan, yakni dalam Putusan MK No. 132/PUU-VII/2009 ihwal pengujian UU No. 10 Tahun 2008 tentang Pemilu Anggota DPR, DPD dan DPRD, MK menyatakan:18 "Bahwa berdasarkan perspektif original intent pembentuk UUD 1945, seluruh hak asasi manusia yang tercantum dalam Bab XA UUD 1945 keberlakuannya dapat dibatasi (vide Pasal 28J ayat (2) UUD 1945) sebagai pasal penutup dari seluruh ketentuan yang mengatur tentang hak asasi manusia dalam Bab XA UUD 1945 tersebut. Berdasarkan penafsiran sistematis (sistematische interpretatie), hak asasi manusia yang diatur dalam Pasal 28A sampai dengan Pasal 28I UUD 1945 tunduk pada pembatasan yang diatur dalam Pasal 28J ayat (2) UUD 1945."

\section{Implikasi Reformasi Politik dan Ketatanegaraan terhadap Dwifungsi ABRI}

Memperhatikan segala wacana mengenai reformasi akhir-akhir ini, reformasi yang dimaksudkan dan dikehendaki oleh massa awam di luar sistem kekuasaan pemerintahan dewasa ini adalah reformasi yang juga menjejas ranah yang lebih mandasar, yaitu moral politik dalam kehidupan berbangsa dan bernegara. Reformasi yang dicitakan adalah reformasi untuk menggerakkan perubahan yang secara strategis mendekonstruksi format lama dalam kehidupan bernegara yang cenderung otokratis ke wujud rekonstruktifnya yang baru, yang lebih demokratis. Inilah reformasi yang menggerakkan perubahan dari model kehidupan bernegara dengan kedaulatan yang cenderung dipusatkan di tangan penguasa tunggal yang

\footnotetext{
17 Ibid., hlm. 43.

${ }^{18}$ Putusan MK No. 132/PUU-VII/2009 perihal Pengujian UU No. 10 Tahun 2008 tentang Pemilu Anggota DPR, DPD dan DPRD.
} 
bersemayam di pusat, ke model kehidupan bernegara dengan kedaulatan yang lebih didistribusikan secara adil ke tangan rakyat (yang masing-masing harus diakui sebagai warga yang berkedudukan sama di hadapan hukum, tanpa kecualinya).

Penegasan bahwa Indonesia merupakan negara hukum, serta pernyataan bahwa kekuasaan kehakiman merupakan kekuasaan yang merdeka, mengandung spirit untuk tidak menjadikan hukum sebagai alat kekuasaan, menegakkan prinsip persamaan di depan hukum dan melindungi campur tangan baik yang bersifat internal maupun eksternal terhadap kekuasaan kehakiman dalam rangka mencegah dan menghindari kegagalan pencapaian keadilan.

Secara mendasar, gerakan reformasi harus diinterpretasikan sebagai suatu upaya yang terorganisir dan sistematis dari bangsa Indonesia untuk mengaktualisasikan nilai-nilai dasar demokrasi, yang disepanjang kekuasaan rezim Orde Baru terlanjur telah dimanipulasi dan diselewengkan. Berdasarkan interpretasi reformasi tersebut, maka agenda nasional harus difokuskan pada upaya pengembangan yang terus menerus terhadap 'indeks demokrasi' (indices of democracy). Indeks itu dapat dikelompokkan ke dalam empat aspek kehidupan berbangsa dan bernegara: Pertama, keberadaan sistem pemilihan umum yang bebas dan adil; kedua, keberadaan pemerintahan yang terbuka, akuntabel dan responsif; ketiga, pemajuan dan perlindungan hak-hak sipil dan politik seluruh warga tanpa kecuali; dan keempat, keberadaan masyarakat yang memiliki rasa percaya diri yang penuh. ${ }^{19}$

Secara konseptual dan strategis, ada empat pilar reformasi yang semestinya menjadi acuan dalam pembaharuan politik, ekonomi, sosial dan lain-lain, termasuk pembaharuan di bidang hukum. Pertama, mewujudkan kembali pelaksanaan demokrasi dalam segala peri kehidupan bermasyarakat, berbangsa dan bernegara. Dalam demokrasi, rakyat adalah sumber dan sekaligus yang bertanggungjawab mengatur dan mengurus diri mereka sendiri. Setiap kekuasaan harus bersumber dan tunduk pada kehendak dan kemauan rakyat. Kedua, mewujudkan kembali pelaksanaan prinsip negara yang berdasarkan atas hukum.

Hukum adalah penentu awal dan akhir segala kegiatan bermasyarakat, berbangsa dan bernegara untuk mewujudkan kebenaran dan keadilan bagi setiap orang. Ketiga, pemberdayaan rakyat di bidang politik, ekonomi, sosial dan lainlain, sehingga terwujud kehidupan masyarakat yang mampu menjalankan tanggung

${ }^{19}$ Muladi, Demokratisasi, Hak. Asasi Manusia, dan Reformasi Hukum di Indonesia, Cetakan Pertama, The Habibie Center, Jakarta, 2002, hlm. 28-29. 
jawab dalam bermasyarakat, berbangsa dan bernegara. Keempat, mewujudkan kesejahteraan umum dan sebesar-besarnya kemakmuran atas dasar keadilan sosial bagi seluruh rakyat. ${ }^{20}$

Demokrasi harus dikembangkan atas dasar saling percaya antara satu dengan yang lainnya, karena kalau tidak ada kepercayaan maka tidak dapat diharapkan banyak akan munculnya demokrasi. Kalau pemerintah tidak memiliki kepercayaan terhadap rakyat, pemerintah akan memonopoli kekuasaan yang ada, segala sesuatu diputuskan sendiri sementara rakyat ditinggalkan. Di samping itu, kita harus memperhatikan bahwa demokrasi juga mempersyaratkan sikap dan perilaku yang moderat serta taat aturan hukum. Kecenderungan ekstrimitas dalam sikap, jelas tidak akan mendukung bagi munculnya demokrasi.

Untuk itu, pertama, harus segera dirumuskan suatu strategi reformasi dan pemulihan yang terintegrasi dan komprehensif; kedua, terdapat kemauan politik yang kuat-khususnya dari para elit-untuk segera keluar dari krisis yang melelahkan; ketiga, harus selalu ada "tekanan sosial" (dalam arti positif) baik secara nasional maupun internasional; keempat, didukung oleh watak kepemimpinan yang profesional dan beretika pada semua tingkatan pemerintahan; kelima, keinginan dari organisasi internasional untuk mendukung reformasi harus sepenuhnya didasarkan atas semangat kemitraan; keenam, rekonsiliasi nasional untuk menyelesaikan berbagai masalah dan kasus-kasus yang dilakukan oleh rezim Orde Baru; ketujuh, komitmen untuk menjunjung prinsip supremasi hukum dan pemerintahan yang baik guna menjamin keadilan, keamanan dan kepastian berdasarkan hukum. ${ }^{21}$

Untuk mewujudkan demokrasi dalam segenap aspek kehidupan, maka substansi reformasi politik untuk demokrasi, meliputi unsur sistem politik dan aspek kehidupan politik.22 Aspek sistem politik yang memerlukan reformasi adalah struktur, kultur, proses, dan produknya. Struktur politik Orde Baru yang ditata berdasarkan pemusatan kekuasaan sehingga mengkondisikan sistem politik otoritarian, merupakan penghalang utama demokratisasi politik. Karenanya, struktur itu direformasi menjadi struktur, berdasarkan distribusi kekuasaan secara relatif berimbang. Tatanan itu hanya dimungkinkan oleh peran rakyat sebagai kekuatan politik. Peran birokrasi sipil dan militer selaku kekuatan politik, jelas dan terbukti melandasi sistem pemusatan

\footnotetext{
${ }^{20}$ Bagir Manan, "Kata Pengantar", dalam buku Slamet Effendy Yusuf dan Umar Basalim, Reformasi Konstitusi Indonesia Perubahan Pertama UUD 1945, Pustaka Indonesia Satu, Jakarta, 2000, hlm. xviii.

${ }^{21}$ Muladi, Demokratisasi,...., Op.Cit., hlm. 32.

${ }^{22}$ Arbi Sanit, Reformasi..., Op.Cit., hlm. 105.
} 
kekuasaan. Karenanya, lembaga kenegaraan itu diperbarui lewat menetralisasikan posisi dan perannya terhadap tatanan kekuasaan.

Reformasi budaya politik dilakukan dengan cara menumbuhkan budaya politik kompetitif, di mana nilai dan kepentingan semua pihak diberikan perhatian yang lebih kurang seimbang, karena semua pihak dimaksudkan mengambil bagian secara aktif untuk berjuang secara rasional. Maka hirarki kekuasaan diganti dengan persamaan kedudukan para aktor politik, sehingga semua pihak harus berpikir dan bersikap secara rasional untuk menjamin penyelesaian konflik (masalah) secara adil dan benar.

Berdasarkan kombinasi tatanan kekuasaan yang terdistribusi secara relatif berimbang dengan budaya politik kompetitif rasional itulah direformasi pola proses politik supaya interaksi kekuasaan berlangsung secara terbuka dan kompetitif serta partisipatif, sehingga kejujuran politik terkondisikan. Akhirnya, reformasi kebijaksanaan publik diarahkan untuk mengubah dan meniadakan peraturan lama yang tidak relevan dengan demokrasi dan menciptakan kebijaksanaan baru yang diperlukan. Arahnya ialah menjadikan segenap kebijaksanaan publik supaya tepat menghadapi masalah dan bermanfaat secara adil bagi rakyat. Reformasi politik yang dicita-citakan seperti itu pada ujung-ujungnya tentulah akan menyangkut juga persoalan reformasi hukum, khususnya hukum konstitusi. Kalaupun bukan persoalan rumusan-rumusan formilnya, reformasi korektif itu tentulah berkenaan dengan pemaknaan interpretatifnya, dan sehubungan dengan hal itu, selanjutnya juga berkenaan dengan pelaksanaannya. ${ }^{23}$

Reformasi sebagai suatu era dan dalam pengertian politis sebagai tatanan atau rezim, harus diartikan sebagai usaha sistematis dari bangsa Indonesia untuk mengaktualisasikan nilai-nilai dasar demokrasi; atau lebih luas lagi untuk mengaudit dan mengaktualisasikan indeks demokrasi yang pada orde lalu telah dimanipulasikan. ${ }^{24}$ Reformasi menurut Mukthie Fadjar, bukan sekedar upaya menumbangkan Soeharto dari kursi kepresidenan, dan bukan pula sekedar upaya untuk mengikis habis KKN. Reformasi yang dikehendaki rakyat adalah upaya menyeluruh untuk merubah paradigma pembangunan masyarakat, bangsa dan negara, dari paradigma kekuasan menjadi paradigma hati nurani dan akal budi. ${ }^{25}$ Perubahan

\footnotetext{
${ }^{23}$ Soetandyo W., Hukum: Paradigma, Metode dan Dinamika Masalabnya, Elsam dan Huma, Jakarta, 2002, hlm. 586.

${ }^{24}$ Muladi, Op.Cit., hlm. 21.

${ }^{25}$ A. Mukthie Fadjar, Reformasi Konstitusi Dalam Masa Transisi Paradigmatik, In-TRANS, Malang, 2003, hlm. 33.
} 
paradigma tersebut mengandung makna perubahan total, fundamental, menyeluruh dan sinergis, sambung dalam semua aspek kehidupan bermasyarakat, berbangsa dan bernegara. Tujuan akhir reformasi adalah terbentuknya sebuah "masyarakat madani", yaitu masyarakat yang demokratis, berkeadilan sosial, dan menjunjung tinggi harkat dan martabat manusia secara beradab dan berbudaya.

Untuk itu, searah dengan tuntutan reformasi, hadirnya aturan hukum yang tegas, demokratis dan bersandar pada prinsip-prinsip keadilan sesungguhnya akan menjadi penuntun ke arah mana politik dan ekonomi akan dibingkai. Akibat kurang tegasnya aturan hukum ataupun kurang mengakarnya aturan hukum yang ada, akan menimbulkan ekses yang merugikan masyarakat karena aturan tersebut hanya akan dipakai sebagai alat penekan dari kekuasaan yang ada.

Munculnya upaya pembaharuan atas keterlibatan sosial-politik ABRI baru terjadi secara intensif setelah jatuhnya kekuasaan Soeharto, Mei 1998. Perubahan utama yang harus dilakukan pada masa transisi ini tertuju pada peninjauan doktrin pertahanan dan keamanan nasional yang bertumpu pada konsep dwifungsi ABRI. Pengejawantahan doktrin ini dalam perkembangannya hanya berhasil menciptakan kemampuanTNI untuk berperan menjamin keamanan internal dalam rangka stabilitas nasional daripada keamanan eksternal yang sesungguhnya menjadi otoritasnya. ${ }^{26}$

Dalam menanggapi berbagai tuntutan perubahan itu TNI-Polri mengkaji ulang posisinya. ABRI baru sadar untuk merespon tuntutan ini lima bulan sejak lengsernya Soeharto, dengan mengeluarkan buku putih yang berjudul "ABRI Abad XXI: Redifinisi, Reposisi dan Reaktualisasi Peran TNI dalam Kehidupan Bangsa". Pemikiran ini oleh ABRI disebut sebagai paradigma baru, sebagai pengganti paradigma ABRI sebagai alat kekuasaan. Empat prinsip reformasi TNI: Pertama, mengubah posisi dan metode tidak harus selalu di depan. Kedua, merubah konsep dari menduduki menjadi mempengaruhi. Ketiga, merubah cara mempengaruhi secara langsung menjadi tidak langsung. Keempat, senantiasa melakukan role sharing (kebersamaan dalam pengambilan keputusan penting kenegaraan dan pemerintahan) dengan komponen bangsa lain (sipil). ${ }^{27}$ Pergeseran paradigma ini mencakup tiga elemen kunci: (1) pemberdayaan kelembagaan fungsional, (2) memerankan TNI sebagai bagian dari sistem nasional, dan (3) peran TNI sesuai dengan konsensus nasional. ${ }^{28}$

\footnotetext{
${ }^{26}$ Muh. Fajrul Falaakh dkk (Tim Penulis), Implikasi..., Op.Cit., hlm. 258.

${ }^{27}$ AE Priyono dkk (Tim Penulis), Warisan..., Loc.Cit.

${ }^{28}$ Muh. Fajrul Falaakh dkk (Tim Penulis), Implikasi..., Op.Cit., hlm. 259.
} 
Paradigma baru TNI ini ditindaklanjuti dalam Sidang Istimewa MPR tahun 1998, yang menghasilkan Ketetapan MPR No. X/MPR/1998 tentang Pokok-Pokok Reformasi Pembangunan Dalam Rangka Penyelamatan dan Normalisasi Kehidupan Nasional sebagai Haluan Negara. Sebagai mandataris MPR, Presiden BJ Habibie harus melaksanakan dan mempertanggungjawabkan ketetapan tersebut.

\section{Hak Politik TNI dalam Pemilu Pasca Reformasi}

Sesungguhnya memilih dalam pemilu adalah hak dasar politik bagi setiap warga negara terlepas dari apapun profesinya. Setiap orang, termasuk tentara dan polisi, juga memiliki hak dasar ini. Karena itu, di negara yang politiknya stabil, tentara dan polisi ikut pemilu. Karena itu pula, anggota TNI dan Polri ikut Pemilu 1955 dan Pemilu Sela 1957.

Namun, hak politik itu kemudian disepakati untuk “ditunda” pelaksanaannya. Sejarah menunjukkan pelaksanaan hak itu pada masa prareformasi telah disalahgunakan sehingga merugikan perkembangan demokrasi Akibatnya hingga Pemilu ke-4 orde reformasi pada 2014 ini, anggota TNI dan Polri belum ikut memilih. ${ }^{29}$

Sebagai agenda penyesuaian peran militer dan pengembalian status polisi yang memiliki watak sipil, pemerintah mengeluarkan Instruksi Presiden No. 2 Tahun 1999 tentang Langkah Kebijakan Dalam Rangka Pemisahan Polri dari ABRI. Langkah ini berorientasi politis, yaitu dalam rangka membangun legitimasi politik. ${ }^{30}$ Ditinjau dari sisi norma hukum, Instruksi Presiden ini jelas bertentangan secara formal maupun material dengan UU No. 20 Tahun 1982 tentang Ketentuan-ketentuan Pokok Pertahanan dan Keamanan Negara, serta Ketetapan MPRS No. XXIV/MPRS/1996 tentang Kebijaksanaan Dalam Bidang Pertahanan dan Keamanan, yang substansinya menguatkan integrasi Polri dengan TNI. Inpres tidak dapat mencabut berlakunya suatu UU.

Pada 1 Pebruari 1999, Presiden BJ Habibie mengesahkan UU No. 2 Tahun 1999 tentang Partai Politik. Pemilu 1999, jelas baru langkah awal dan belum mampu menjadi sarana partisipasi politik rakyat. Harusnya, pemilu merupakan aktualisasi nyata demokrasi di mana rakyat bisa menyatakan kedaulatannya terhadap negara

\footnotetext{
${ }^{29}$ Hermawan Sulistyo, "Netralitas TNI/Polri dalam Pemilu”, Kompas, Rabu, 22 Januari 2014, hlm. 7.

${ }^{30}$ Ibid., hlm. 263.
} 
dan pemerintahan. Melalui Pemilu ini, rakyat menentukan siapa yang menjalankan dan mengawasi jalannya pemerintahan negara. Di sini, rakyat memilih dan melakukan pengawasan terhadap wakil-wakilnya. Hanya saja, persiapan Pemilu 1999 perangkat perundang-undangannya masih memihak status quo dan tidak mencerminkan amanat reformasi. Sekurang-kurangnya ada dua penjelasan. Pertama, Pemilu dipersiapkan secara tergesa-gesa sehingga tidak memberi kesempatan kepada partai politik untuk melakukan sosialisasi program kepada masyarakat luas. Kedua, perangkat perundang-undangan yang disiapkan masih bias kepentingan partai Orde Baru. ${ }^{31}$ Pemilu 1999 dilaksanakan dengan menggunakan sistem proporsional berdasarkan stelsel daftar.

Cacat mendasar dari pelaksanaan Pemilu 1999 ditandai oleh masih adanya wakil ABRI yang duduk di DPR tanpa mengikuti proses pemilu. Bagi kelompok oposisi radikal, masih dipertahankannya wakil TNI di parlemen, menunjukkan bahwa pemerintahan Habibie tidak memiliki komitmen yang sungguh-sungguh dalam mengonsolidasikan demokrasi. ${ }^{32}$

Di dalam UU No. 4 Tahun 1999 tentang Susunan dan Kedudukan MPR, DPR dan DPRD Pasal 11 ditegaskan: (1) Pengisian Anggota DPR dilakukan berdasarkan hasil Pemilihan Umum dan pengangkatan; (2) DPR terdiri atas: a. anggota partai politik hasil Pemilihan Umum; b. anggota ABRI yang diangkat; (3) Jumlah Anggota DPR adalah 500 orang dengan rincian: a. anggota partai politik hasil Pemilihan Umum, sebanyak 462 orang; b. anggota ABRI yang diangkat, sebanyak 38 orang.

Pengangkatan anggota DPR dari ABRI sebanyak 38 orang sebagai 'imbangan atau kompensasi politik' karena anggota ABRI tidak menggunakan hak memilih (Pasal 30 UU No. 3 Tahun 1999 tentang Pemilihan Umum).

Pada tahun 2000, terjadi perubahan mendasar dalam hubungan TNI dan Polri pasca perubahan UUD 1945, yaitu lahirnya Ketetapan MPR No. VI/MPR/2000 tentang Pemisahan TNI dan Polri, dan Ketetapan MPR No. VII/MPR/2000 tentang Peran TNI dan Peran Polri. Untuk menindaklanjuti Ketetapan MPR tersebut dikeluarkanlah UU No. 2 Tahun 2002 tentang Kepolisian Negara RI dan UU No. 3 Tahun 2002 tentang Pertahanan Negara.

Konsideran Ketetapan MPR No. VI/MPR/2000 menegaskan bahwa salah satu tuntutan reformasi dan tantangan masa depan adalah dilakukannya demokratisasi,

\footnotetext{
${ }^{31}$ Mulyana W. Kusumah dkk., Menata Politik Paska Reformasi, KIPP Indonesia, Jakarta, 2000, hlm. 1-2.

${ }^{32}$ AE Priyono dkk (Tim Penulis), Warisan..., Loc.Cit., hlm. 115.
} 
maka diperlukan reposisi dan restrukturisasi ABRI. Bahwa dengan adanya kebijakan dalam bidang pertahanan/keamanan telah dilakukan penggabungan Angkatan Darat, Angkatan Laut, Angkatan Udara, dan Kepolisian Negara Republik Indonesia dalam ABRI. Sebagai akibat dari penggabungan tersebut terjadi kerancuan dan tumpang tindih antara peran dan fungsi TNI sebagai kekuatan pertahanan negara dengan peran dan tugas Kepolisian Negara RI sebagai kekuatan keamanan dan ketertiban masyarakat. Peran sosial politik dalam dwifungsi ABRI menyebabkan terjadinya penyimpangan peran dan fungsi TNI dan Polri yang berakibat tidak berkembangnya sendi-sendi demokrasi dalam kehidupan berbangsa, bernegara, dan bermasyarakat.

Perihal keikutsertaan TNI dan Polri dalam penyelenggaraan negara, telah ditegaskan dalam Pasal 5 dan Pasal 10 Ketetapan MPR No. VII/MPR/2000. Di dalam Pasal 5 ditegaskan: (1) Kebijakan politik negara merupakan dasar kebijakan dan pelaksanaan tugas TNI; (2) TNI bersikap netral dalam kehidupan politik dan tidak melibatkan diri pada kegiatan politik praktis; (3) TNI mendukung tegaknya demokrasi, menjunjung tinggi hukum dan hak asasi manusia; (4) Anggota TNI tidak menggunakan hak memilih dan dipilih. Keikutsertaan TNI dalam menentukan arah kebijakan nasional disalurkan melalui Majelis Permusyawaratan Rakyat paling lama sampai dengan 2009; . (5) Anggota TNI hanya dapat menduduki jabatan sipil setelah mengundurkan diri atau pensiun dari dinas ketentaraan.

Pasal 10 menegaskan sebagai berikut: (1) Kepolisian Negara Republik Indonesia bersikap netral dalam kehidupan politik dan tidak melibatkan diri pada kegiatan politik praktis; (2) Anggota Kepolisian Negara Republik Indonesia tidak menggunakan hak memilih dan dipilih. Keikutsertaan Kepolisian Negara Republik Indonesia dalam menentukan arah kebijakan nasional disalurkan melalui Majelis Permusyawaratan Rakyat paling lama sampai dengan tahun 2009; (3) Anggota Kepolisian Negara Republik Indonesia dapat menduduki jabatan di luar kepolisian setelah mengundurkan diri atau pensiun dari dinas kepolisian.

Penempatan TNI dan Polri (ABRI) di MPR sampai 2009 secara nyata berlawanan dengan kesepakatan yang semula diambil oleh TNI sendiri ketika menyampaikan sikap dan pandangan TNI terhadap isu-isu aktual, bahwa posisi Fraksi ABRI di DPR hanya sampai 2004. Perubahan ini terjadi karena kekhawatiran munculnya fragmentasi dan politisasi militer. Karena itu dalam masa transisi ini keanggotaan ABRI di MPR masih dipertahankan. Sekalipun jumlah anggota Fraksi ABRI di MPR hanya 38 orang, akan tetapi keberadaannya sangat menentukan proses pengambilan 
keputusan strategis bangsa, termasuk dalam penentuan arah politik masa transisi ini. $^{33}$

Ketentuan perundang-undangan di Indonesia kemudian membatasi hak memilih dan dipilih bagi anggota TNI dan Kepolisian dalam UU No. 2 Tahun 2002 tentang Kepolisian Negara RI dan UU No. 34 Tahun 2004 tentang TNI. Di dalam ketentuan Pasal 28 UU Polri ditegaskan: (1) Kepolisian Negara Republik Indonesia bersikap netral dalam kehidupan politik dan tidak melibatkan diri pada kegiatan politik praktis; (2) Anggota Kepolisian Negara Republik Indonesia tidak menggunakan hak memilih dan dipilih; (3) Anggota Kepolisian Negara Republik Indonesia dapat menduduki jabatan di luar kepolisian setelah mengundurkan diri atau pensiun dari dinas kepolisian.

Adapun untuk anggota TNI, ketentuan Pasal 39 UU TNI menegaskan prajurit dilarang terlibat dalam: 1) kegiatan menjadi anggota partai politik; 2) kegiatan politik praktis; 3) kegiatan bisnis; 4) kegiatan untuk dipilih menjadi anggota legislatif dalam pemilihan umum dan jabatan politis lainnya.

Berbeda dengan Pemilu sebelumnya, Pemilu tahun 2004 untuk memilih anggota DPR, DPRD Propinsi dan DPRD Kabupaten/Kota dilaksanakan dengan sistem proporsional dengan daftar calon terbuka dengan penerapan daftar nomor urut. Pemilu untuk memilih anggota DPD dilaksanakan dengan sistem distrik berwakil banyak.

Pada 2004, bangsa Indonesia mendapat ujian yang berat karena disibukkan dengan banyaknya jadwal pemilihan, mulai dari Pemilu Anggota DPR, DPD, DPRD sampai dengan Pemilu Presiden dan Wakil Presiden. Dan untuk pertama kalinya dalam sejarah pemilu di Indonesia, perselisihan hasil Pemilu Legislatif 2004 diadili dan diputus oleh Mahkamah Konstitusi. Sebanyak 273 perkara masuk ke lembaga pelaksanaan kekuasaan kehakiman baru ini, dan Mahkamah Konstitusi telah menuntaskan tugas konstitusionalnya dengan memutus seluruh perkara dengan putusan yang bersifat final. ${ }^{34}$

Di dalam Pemilu 2004, larangan bagi TNI dan Polri untuk memilih, sebagaimana ditentukan dalam UU No. 3 Tahun 1999 dikuatkan kembali oleh Pasal 145 UU No. 12 Tahun 2003 tentang Pemilu Anggota DPR, DPD, dan DPRD, yang menyatakan “Dalam Pemilu tahun 2004, anggota Tentara Nasional Indonesia dan anggota

\footnotetext{
${ }^{33}$ Muh. Fajrul Falaakh dkk (Tim Penulis), Implikasi..., Op.Cit., hlm. 274-275.

${ }^{34}$ Berita Mabkamah Konstitusi, Edisi Khusus, 2004, hlm. 4.
} 
Kepolisian Negara Republik Indonesia tidak menggunakan hak memilihnya". Pengaturan yang sama juga muncul dalam Pasal 102 UU No. 23 Tahun 2003 tentang Pemilu Presiden dan Wakil Presiden, yang menegaskan bahwa "Dalam Pemilu Presiden dan Wakil Presiden tahun 2004 anggota Tentara Nasional Indonesia dan anggota Kepolisian Negara Republik Indonesia tidak menggunakan hak memilih".

Pemilu 2009 menggunakan sistem Pemilu proporsional terbuka dengan penerapan suara terbanyak. Semula UU No. 27 Tahun 2009 tentang MPR, DPR, DPD dan DPRD menentukan sistem Pemilu proporsional terbuka dengan penerapan daftar nomor urut, yang kemudian dikoreksi oleh Mahkamah Konstitusi melalui Putusan MK No. 22-24/PUU-VI/ 2008 menjadi sistem proporsional terbuka dengan suara terbanyak. ${ }^{35}$

Berkaitan dengan keterlibatan TNI dan Polri dalam Pemilihan Presiden dan Wakil Presiden 2009, Pasal 260 UU No. 42 Tahun 2008 tentang Pemilihan Umum Presiden dan Wakil Presiden, kembali menegaskan bahwa "Dalam Pemilihan Presiden dan Wakil Presiden tahun 2009, anggota Tentara Nasional Indonesia dan anggota Kepolisian Negara Republik Indonesia tidak menggunakan haknya untuk memilih". Begitupun dalam hal keanggotaan TNI dan Polri di dalam DPR juga sudah dihapuskan, karena di dalam Pasal 67 UU No. No. 27 Tahun 2009 telah ditegaskan, “DPR terdiri atas anggota partai politik peserta pemilihan umum yang dipilih melalui pemilihan umum". Adapun untuk Pemilu Legislatif 2009, ketentuan dalam UU No. 10 Tahun 2008 tentang Pemilihan Umum Anggota DPR, DPD dan DPRD Pasal 318 menegaskan “Dalam Pemilu 2009, anggota TNI dan anggota Polri tidak menggunakan haknya untuk memilih".

Berkenaan dengan Pemilu Legislatif 2014, anggota TNI dan Polri ditegaskan tidak menggunakan haknya untuk memilih. Penegasan itu diatur dalam Pasal 326 UU No. 8 Tahun 2012 tentang Pemilihan Umum Anggota DPR, DPD dan DPRD. Adapun untuk Pemilihan Presiden dan Wakil Presiden, oleh karena UU No. 42 Tahun 2008 tidak diganti dan masih terus berlaku, timbul persoalan dalam hal ketentuan Pasal 260 yang mengatur perihal hak memilih anggota TNI dan Polri, karena hanya dibatasi untuk pemilihan Presiden dan Wakil Presiden 2009. Dengan demikian untuk pemilihan Presiden dan Wakil Presiden 2014 belum ada pengaturannya. Hal ini dapat saja menimbulkan tafsir bahwa anggota TNI dan Polri

${ }^{35}$ Ni’matul Huda, Dinamika Ketatanegaraan Indonesia dalam Putusan Mabkamah Konstitusi, FH UII Press, Yogyakarta, 2011, hlm. 183. 
dapat menggunakan hak pilihnya dalam pemilihan Presiden dan Wakil Presiden 2014, meskipun UU TNI maupun UU Polri melarang TNI dan Polri terlibat dalam politik praktis. Memang sebaiknya hal ini ada pengaturan yang spesifik, misalnya melalui perubahan UU No. 42 Tahun 2008 khususnya Pasal 260 atau dikeluarkan Perppu untuk menentukan ketidakberlakuan Pasal 260 tersebut.

Belakangan muncul gugatan pengujian UU No. 42 Tahun 2008 terhadap UUD Negara RI Tahun 1945 yang diajukan ke Mahkamah Konstitusi (MK) oleh Ifdal Kasim (Mantan Ketua Komnas HAM RI) dan Supriyadi Widodo Eddyono (sebagai Pemohon). Dalam Putusan MK No. 22/PUU-XII/2014, Mahkamah menyatakan bahwa Pasal 260 inkonstitusional bersyarat. Artinya, frasa "tahun 2009" dalam Pasal 260 UU No. 42 Tahun 2008 tentang Pemilihan Presiden dan Wakil Presiden bertentangan dengan UUD sepanjang tidak dimaknai “Tahun 2014” dan tidak mempunyai kekuatan hukum mengikat sepanjang tidak dimaknai “Tahun 2014”. ${ }^{36}$ Dengan lahirnya putusan MK tersebut, 'kekosongan" pengaturan untuk pemilihan Presiden dan Wakil Presiden tahun 2014 bagi TNI dan Polri sudah tercukupi landasan hukumnya.

Akar masalah "penundaan hak" itu adalah kepercayaan publik politik. TNI dan Polri harus mampu mengembalikan kepercayaan itu. Caranya, manakala dalam rangkaian Pemilu 2014 ini keduanya (TNI dan Polri) “hanya” diberi tugas pengamanan pemilu, tugas itu harus dilaksanakan sebaik-baiknya. Suatu tugas yang hanya bisa dilakukan dengan baik jika TNI dan Polri tidak terlibat dalam dunia politik. Dengan kalimat lain, netralitas dalam peran-peran pengamanan pemilu menjadi keniscayaan. ${ }^{37}$

Kebijakan yang diambil oleh pemerintah Indonesia untuk menangguhkan hak pilih TNI dan Polri tidak bertentangan dengan HAM karena hal itu merupakan politik hukum pembentuk perundang-undangan yang telah ditegaskan dalam berbagai peraturan perundang-undangan yang melarang secara tegas keterlibatan TNI dan Polri dalam politik praktis.

\section{Penutup}

Dari uraian dan analisis terhadap dua permasalahan utama dalam penelitian ini dapat disimpulkan sebagai berikut. Pertama, implikasi reformasi politik dan

${ }^{36}$ Lihat Putusan MK No. 22/PUU-XII/2014 tentang Pengujian UU No. 42 Tahun 2008 tentang Pemilihan Presiden dan Wakil Presiden.

${ }^{37}$ Hermawan Sulistyo, "Netralitas TNI/Polri..., Loc.Cit. 
ketatanegaraan tahun 1998 terhadap dwifungsi ABRI, yakni adanya perubahan paradigmatik di tubuh ABRI melalui empat prinsip reformasi TNI: Pertama, mengubah posisi dan metode tidak harus selalu di depan. Kedua, merubah konsep dari menduduki menjadi mempengaruhi. Ketiga, merubah cara mempengaruhi secara langsung menjadi tidak langsung. Keempat, senantiasa melakukan role sharing (kebersamaan dalam pengambilan keputusan penting kenegaraan dan pemerintahan) dengan komponen bangsa lain (sipil).

Kedua, dipisahkannya TNI dan Polri melalui Ketetapan MPR No. VI/MPR/ 2000 dan Ketetapan MPR No. VII/MPR/2000 tentang Peran TNI dan Peran Polri. Ketiga, TNI dan Polri tidak diperkenankan untuk menggunakan hak pilihnya dalam semua Pemilu pasca reformasi dilatarbelakangi oleh adanya tuntutan masyarakat pasca jatuhnya Orde Baru yang hegemonik dan memanfaatkan TNI dan Polri untuk melindungi kepentingan rezim Orde Baru melalui kebijakan Dwifungsi ABRI yang diselewengkan.

Penelitian ini merekomendasikan, perlu dikaji kembali perihal hak pilih dan dipilih TNI dan Polri dalam Pemilu dalam batas waktu yang ditentukan, agar tidak terjadi pelanggaran HAM bagi setiap warga negara Indonesia.

\section{Daftar Pustaka}

Donald, Parulian, Menggugat Pemilu, Pustaka Sinar Harapan, Jakarta, 1997.

Fajrul Falaakh, Muh., dkk (Tim Penulis), Implikasi Reposisi TNI-Polri Di Bidang Hukum, FH UGM, Yogyakarta, 2001.

Firmansyah, Persaingan, Legitimasi Kekuasaan,Dan Marketing Politik, Pembelajaran Politik Pemilu 2009, Yayasan Obor Indonesia, Jakarta, 2010.

Gaffar, Afan, Politik Indonesia; Transisi Menuju Demokrasi, Pustaka Pelajar, Yogyakarta, 1999.

Held, David, Demokrasi \& Tatanan Global Dari Negara Modern Hingga Pemerintahan Kosmopolitan, Pustaka Pelajar, Yogyakarta, 2004.

Models of Democracy, diterjemahkan oleh Abdul Haris, Akbar Tandjung Institute, Jakarta, 2007.

Huda, Ni'matul, Hukum Tata Negara Indonesia, Rajagrafindo Persada, Jakarta, 2005.

, Dinamika Ketatanegaraan Indonesia dalam Putusan Mahkamah Konstitusi, FH UII Press, Yogyakarta, 2011.

Latif, Yudi dan Idi Subandy (ed.), Bahasa dan Kekuasaan Politik Wacana di Panggung Orde Baru, Cet. Kedua, Mizan, Bandung, 1996. 
Muladi, Demokratisasi, Hak Asasi Manusia, dan Reformasi Hukum di Indonesia, Cetakan Pertama, The Habibie Center, Jakarta, 2002.

Priyono, AE., dkk (Tim Penulis), Warisan Orde Baru, Institut Studi Arus Informasi bekerjasama Universitas Melbourne dan UusAid, Jakarta, 2005.

R. Saragih, Bintan, Lembaga Perwakilan dan Pemilihan Umum Di Indonesia, Gaya Media Pratama, Jakarta, 1987.

Soemantri M., Sri, Sistem Pemilu Dalam Ketatanegaraan Indonesia, Majalah PERSAHI, Nomor Ketiga, Januari 1990.

Sulistyo, Hermawan, "Netralitas TNI/Polri dalam Pemilu”, Kompas, Rabu, 22 Januari 2014.

Thaib, Dahlan dan Ni'matul Huda (ed.), Pemilu dan Lembaga Perwakilan Dalam ketatanegaraan Indonesia, Jurusan HTN Fakultas Hukum UII, Yogyakarta, 1992.

W. Kusumah, Mulyana dkk., Menata Politik Paska Reformasi, KIPP Indonesia, Jakarta, 2000.

, Tegaknya Supremasi Hukum Terjebak antara Memilih Hukum dan Demokrasi, Remaja Rosdakarya, Bandung, 2001.

W., Soetandyo, Hukum: Paradigma, Metode dan Dinamika Masalahnya, Elsam dan Huma, Jakarta, 2002.

Berita Mahkamah Konstitusi, Edisi Khusus, 2004.

Undang-Undang Dasar Negara RI Tahun 1945

Ketetapan MPRS No. XXIV/MPRS/1996 tentang Kebijaksanaan Dalam Bidang Pertahanan dan Keamanan.

Ketetapan MPR No. VI/MPR/2000 tentang Pemisahan TNI dan Polri

Ketetapan MPR No. VII/MPR/2000 tentang Peran TNI dan Peran Polri.

UU No. 20 Tahun 1982 tentang Ketentuan-ketentuan Pokok Pertahanan dan Keamanan Negara.

UU No. 2 Tahun 2002 tentang Kepolisian Negara RI

UU No. 34 Tahun 2004 tentang Tentara Nasional Indonesia.

UU No. 10 Tahun 2008 tentang Pemilu Anggota DPR, DPD dan DPRD

UU No. 42 Tahun 2008 tentang Pemilihan Umum Presiden dan Wakil Presiden.

UU No. 8 Tahun 2012 tentang Pemilu Anggota DPR, DPD dan DPRD

Putusan MK No. 132/PUU-VII/2009 perihal Pengujian UU No. 10 Tahun 2008 tentang Pemilu Anggota DPR, DPD dan DPRD. 